University of Chicago Law School

Chicago Unbound

Journal Articles

Faculty Scholarship

1977

\title{
The Rule of Reason and the Economic Approach: Reflections on the Sylvania Decision
}

Richard A. Posner

Follow this and additional works at: https://chicagounbound.uchicago.edu/journal_articles

Part of the Law Commons

\section{Recommended Citation}

Richard A. Posner, "The Rule of Reason and the Economic Approach: Reflections on the Sylvania Decision," 45 University of Chicago Law Review 1 (1977).

This Article is brought to you for free and open access by the Faculty Scholarship at Chicago Unbound. It has been accepted for inclusion in Journal Articles by an authorized administrator of Chicago Unbound. For more information, please contact unbound@law.uchicago.edu. 


\title{
The \\ University \\ of Chicago \\ Law Review
}

\section{The Rule of Reason and the Economic Approach: Reflections on the Sylvania Decision}

\author{
Richard A. Posner †
}

In the absence of antitrust prohibitions, manufacturers commonly restrict competition among their distributors or dealers. They may forbid the dealer to sell from any location other than that designated in the dealership agreement ("location clause"), set maximum or minimum resale prices, assign exclusive territories to dealers, reserve certain customers to the manufacturer, forbid distributors to sell to other than authorized dealers, or forbid dealers to sell to other dealers. One restriction on competition among dealers, resale price maintenance (placing a floor under the dealer's resale price), was held to be illegal per se under section 1 of the Sherman Act as early as 1911 , in the Dr. Miles case. ${ }^{1}$ But the legality of nonprice restrictions in distribution was not even considered by the Supreme Court until it decided the White Motor case in 1963. ${ }^{2}$ The Court in White Motor reversed a summary judgment entered in favor of the government, holding that it was premature to deem the particular restrictions involved (exclusive dealer territories and reservation of certain customers to the manufacturer) illegal per se. Four years later, the Court in Schwinn ${ }^{3}$ held that such restrictions were indeed illegal per se when imposed in contracts of sale. On the other hand, if the dealership agreement created an agency relation-

$\dagger$ Professor of Law, The University of Chicago. This article is adapted from a talk given on November 2, 1977, to an Antitrust Law Briefing Conference sponsored by the Federal Bar Association. Robert H. Bork and Kenneth W. Dam commented helpfully on a previous draft.

1 Dr. Miles Medical Co. v. John D. Park \& Sons Co., 220 U.S. 373 (1911).

2 White Motor Co. v. United States, 372 U.S. 253 (1963).

${ }^{3}$ United States v. Arnold, Schwinn \& Co., 388 U.S. 365 (1967). 
ship between dealer and manufacturer, a nonprice restriction on competition among dealers was not illegal per se. Last term, ten years after Schwinn, the Court in Continental T.V., Inc. v. GTE Sylvania Inc. ${ }^{4}$ repudiated Schwinn and held that nonprice restrictions on dealer competition are not illegal per se even if imposed in a sales contract.

The Sylvania decision has generated considerable excitement in the antitrust defense bar. The Court seemed to go out of its way to overrule Schwinn: it could, as urged by Justice White in his concurring opinion, have adopted the distinction whereby the lower court upheld the legality of Sylvania's location clause without questioning Schwinn. ${ }^{5}$ Furthermore, the Court's opinion places unusual emphasis on the role of economics in deciding antitrust cases, including "Chicago" economics, which is hostile to many of the traditional rules of antitrust liability.

My interest in Sylvania is based not only on the fact that it is one of the most discussed antitrust decisions of recent years. I briefed and argued the Schwinn case for the government. Subsequently, my views on the proper treatment of restrictions in distribution under the antitrust laws took a 180-degree turn, and the article expressing my new thinking was heavily cited by the majority in Sylvania. ${ }^{6}$

\section{From Schwinn to Sylvania}

To understand the possible significance of Sylvania for the development of antitrust doctrine, it is necessary to go back to the government's brief in Schwinn. ${ }^{7}$ The brief did not argue that restricting competition among one's distributors was illegal per se. It argued that the adverse effect of such a restriction on competition

+ 97 S. Ct. 2549 (1977).

5 The Ninth Circuit and Mr. Justice White thought Schwinn distinguishable for two reasons. First, Sylvania's action did not restrict intrabrand competition as severely because Sylvania, unlike Schwinn, did not limit the territories where or the customers to whom its dealers could sell. Second, Sylvania's market share was much smaller than Schwinn's at the time they adopted their respective restricted distribution systems and so the restraints imposed by Sylvania had more potential for increasing interbrand competition. See $97 \mathrm{~S}$. Ct. 2563 (White, J., concurring); 537 F.2d 980, 988-92 (9th Cir. 1976) (en banc), aff'd on other grounds, 97 S. Ct. 2549 (1977).

- Posner, Antitrust Policy and the Supreme Court: An Analysis of the Restricted Distribution, Horizontal Merger and Potential Competition Decisions, 75 Colum. L. Rev. 282 (1975); see 97 S. Ct. at 2557 n.13, 2559 nn.18-21 \& 2561. See also 97 S. Ct. at 2568 n.10. (White, J., concurring). A revised version of the relevant portions of that article appears in R. POSNER, Antrtrust Law: An Economic Perspective 147-66 (1976).

${ }^{7}$ Brief for the United States, United States v. Arnold, Schwinn \& Co., 388 U.S. 365 (1967). 
at the dealer level created a presumption of illegality that could be rebutted, in principle at least, by showing that the restriction had an offsetting procompetitive effect in enabling the manufacturer to market his product more effectively in competition with other manufacturers. The government brief was profoundly skeptical, however, that this showing could ever be made except possibly by a small and struggling new entrant. Indeed, the government thought that restrictions on competition in distribution imposed by an established manufacturer were likely to reduce competition at the manufacturing level as well as at the dealer level. Specifically, the brief suggested that Schwinn had sought to restrict the distribution of its bicycles in order to reinforce an image of superior quality that would reduce the substitutability of other bicycle brands and thus increase Schwinn's monopoly power in the bicycle market.

This analysis reflected the then prevailing thinking of the economics profession on restricted distribution. The Supreme Court, to its credit, was not convinced, but neither was it persuaded that restricted distribution was sufficiently innocuous (or beneficial) to justify rejection of the per se approach. The Court, in an opinion by Justice Fortas, adopted an arbitrary compromise. It held that restrictions on distribution were illegal per se when imposed in sales contracts but not when imposed in agency contracts, even though it had recently held, in Simpson v. Union Oil Company, that resale price maintenance in an agency contract was illegal per se. ${ }^{8}$ Simpson precluded the Court in Schwinn from simply deeming restrictions in distribution outside the reach of section 1 of the Sherman Act when accomplished through agency contracts. So, to distinguish Simpson, the Court observed that the "net effect" of Schwinn's restrictive consignment agreements was "to preserve and not to damage competition in the bicycle market." ${ }^{\text {B }}$ But this statement undermined the Court's blanket condemnation of the identical restrictions when imposed in contracts of sale.

The lower federal courts were plainly unhappy with the per se rule of Schwinn and exercised their ingenuity to find exceptions to the rule..$^{10}$ Meanwhile, academic opinion was changing. Lester Telser's pioneering article on resale price maintenance, ${ }^{11}$ though pub-

377 U.S. 13 (1964).

- 388 U.S. at 382.

in The cases are collected in note 14 of the Court's opinion in Sylvania, 97 S. Ct. at 2557. For an exhaustive analysis of the evolution of restricted distribution law to the eve of Syluania, see ABA antitrust Section, Monograph No. 2, Vertical Restrictions Limiting INTRABRAND COMPETITION (1977).

"Telser, Why Should Manufacturers Want Fair Trade? 3 J. LAw \& Econ. 86 (1960). 
lished well before the Schwinn case was decided, began winning more adherents among academic economists and lawyers. Telser had argued that manufacturers impose minimum resale prices on their dealers not in order to give the latter monopoly profits, which would be an absurd motivation for a manufacturer, but to induce them to provide the optimal level of presale services. ${ }^{12}$ Dealers would compete with each other in offering successively greater services until their marginal cost curve rose to intersect the price fixed by the manufacturer. Therefore, the manufacturer could, simply by altering that price, automatically vary the level of dealer presale services provided. This analysis can easily be extended to nonprice restrictions. ${ }^{13}$ The manufacturer gives the dealer an exclusive territory so that the dealer can charge a price that will support the level of services desired by the manufacturer. The dealer will provide that level of services rather than pocket the difference between a high price and the cost of distribution with little service because, if he does not, the manufacturer will reassign the territory to another dealer.

One reason why Telser's analysis was not more influential at the time Schwinn was decided is that many economists viewed the presale services encouraged by resale price maintenance and cognate nonprice restrictions as of dubious value to consumers, ${ }^{14}$ a view reflected in the government's brief in Schwinn. These services were thought to be forms of advertising, and economists in this period regarded advertising as a socially wasteful activity that served only to reduce the elasticity of demand for advertised products. In particular, it was thought that heavy advertising convinced the consuming public, without any basis in real differences among brands of the same product, that less heavily advertised brands were not good substitutes for more heavily advertised ones. Acceptance of this view of advertising has receded in recent years. Economists are more likely now to regard advertising as a source of genuine consumer information, sometimes irrespective of its content. ${ }^{15}$ In addition, studies have shown that heavy advertising is associated with unsta-

12 He also argued that in some cases manufacturers might adopt resale price maintenance in order to shore up a manufacturers' cartel. This possibility is discussed in text and notes at notes 21-22 infra.

${ }^{13}$ As demonstrated in Bork, The Rule of Reason and the Per Se Concept: Price Fixing and Market Division, (pt. 2), 75 YaLE L.J. 373 (1966).

14 For a representative specimen of this thinking, see Comanor, Vertical Territorial and Customer Restrictions: White Motor and Its Aftermath, 81 HARv. L. REv. 1419, 1429-30 (1968).

${ }^{15}$ See, e.g., Nelson, Information and Consumer Behavior, 78 J. PoL. Econ. 311 (1970). 
ble consumer brand preferences-intensive advertising does not cement consumer loyalty to the advertised brand but, on the contrary, is the recourse of sellers who have difficulty holding on to their customers. ${ }^{16}$ It is a weapon of competition rather than of monopoly.

Not all economists and lawyers knowledgeable in economics who write on monopoly questions, perhaps not even most, view restricted distribution so benignly. Nevertheless, the profession now views restricted distribution more favorably than it did when Schwinn was decided. Justice Fortas's skepticism concerning the government's economic arguments in Schwinn has been, tentatively at least, vindicated.

\section{The Scope of Sylvania}

This article is not centrally concerned with the question whether the Court in Sylvania was correct in overruling Schwinn. Obviously I think the decision is good economics, and because it is well settled that per se illegality is appropriate only when there are grounds for confidence that a practice is on balance anticompetitive, good antitrust law as well. A more difficult question is whether the Court should have followed the principle of stare decisis and avoided overruling so recent a precedent. I can think of no compelling reason why. No doubt some firms relied on that part of the Schwinn decision which allowed manufacturers to restrict distribution by means of consignment agreements, but Sylvania did not disturb their reliance. The only people who relied to their detriment on the per se rule laid down in Schwinn were the plaintiffs in Sylvania-type cases.

More interesting and problematic than the merits of Sylvania are the many questions regarding both substance and method in antitrust law that the opinion raises. How many other antitrust precedents must the Court in logic re-examine, having embraced, I believe for the first time, the "free rider" concept? ${ }^{17}$ Will the Court's strong endorsement of franchise distribution and, relatedly, of the primacy of interbrand competition lead it to adopt more permissive rules concerning other restrictions on intrabrand competition that sellers impose on their franchised dealers and distributors? How far is the Court prepared to press the suggestion in the Sylvania opinion that economic considerations should be dominant in the decision of antitrust cases? And what precisely is the Rule of Reason inquiry

"See Telser, Advertising and Competition, 72 J. PoL. Econ. 537 (1964).

17 See 97 S. Ct. at 2561. 
envisaged by the Court in restricted distribution cases, now that they have been removed from the per se category? These questions are explored in the remainder of this article.

\section{A. Implications of the Free-Rider Concept}

I said earlier that the reason why a manufacturer might want to restrict competition in the distribution of his product is to evoke the optimal level of dealer presale services. As the Court in Sylvania noted, the restriction is necessary because in its absence any dealer who offered presale services would be inviting competing dealers to provide no (or fewer) services and thereby underprice him. This "free-riding" danger would deter dealers from offering presale services, at least in the optimum amount.

The territorial system of the soft-drink companies, currently under challenge by the FTC (which is, however, re-examining the case in light of Sylvania), nicely illustrates the nature of the freerider problem. ${ }^{18}$ The Coca Cola Company considers it very important that Coke be available to the consuming public in vending machines in bars, game rooms, athletic stadiums, and other locations where a sudden onset of thirst may induce the consumer to try, and it is hoped like, Coke. The cost of distribution through thousands of scattered low-volume outlets is very high, however, and if Cokes sold at these locations were priced to cover the full cost of distribution, the price would be so high that Coca Cola's promotional objective would be defeated. Accordingly, each bottlerfranchisee is given an exclusive territory in order to encourage him to maintain a below-cost price (that is, to "advertise" in the manner found to be most effective in the soft-drink industry) in these outlets and recoup his losses by charging a price well above cost in the supermarkets, where the steady customer buys. This system of pricing could not be sustained if there were competition among bottlers, for then some bottlers would do no promotional below-cost selling but would instead cater only to the supermarket trade stimulated by the bottlers who did. Stated otherwise, many bottlers would take a free ride on the taste for the product created by the promotional practices of the bottler who made Coke widely available at low prices.

A more conventional example of the free-riding problem, closer to Sylvania itself, is provided by the facts in United States $v$. Gen-

18 See Coca Cola Co., [1973-1976 Transfer Binder] Trade REg. REp. (CCH) ๆ 21,010 (FTC, initial decision, Oct. 8, 1975). 
eral Motors Corp. ${ }^{19}$ In the late 1950's, discount houses in Los Angeles were offering new Chevrolets to the public at bargain prices. They usually obtained these cars from Chevrolet dealers located across town. A cooperating dealer, because he offered no presale services in connection with the sale of the cars through discount houses, could offer the discount house an attractive price, and the discount house could get by with a small mark-up over that price because it offered few presale services. Customers of the discount houses probably utilized the presale services provided by other dealers before striking their bargains at the discount house. It is evident that if the discount selling had become sufficiently widespread, Chevrolet dealers would have become much less willing to offer presale services, at least without the awkward expedient of charging the potential customer for the service itself (for example, by levying an entrance fee to the dealer showroom).

All this the Supreme Court in Sylvania was well aware of, but it may not have been fully aware of the potential reach of the freerider concept. The Court must have realized, because Justice White emphasized the point in his concurring opinion, ${ }^{20}$ that the concept applies with equal force to resale price maintenance. The Court offered, however, two reasons for distinguishing resale price maintenance from nonprice restrictions in distribution. ${ }^{21}$ The first is that resale price maintenance can be used to bolster collusion at the manufacturer level: if colluding manufacturers have fixed the retail as well as the wholesale price, then one of the manufacturers who is cheating his fellows by undercutting the cartel price cannot pretend that his market share is increasing only because the retailers who carry his product have decided, for their own reasons, to accept a lower mark-up over the wholesale price of his product. But this collusion-enhancing effect of resale price maintenance depends on each retailer's handling only one manufacturer's brand of the product in question, which is the exceptional rather than the normal resale price maintenance situation. The retailer who handles the brands of several manufacturers will increase his purchases of, and his sales efforts for, the brand of the manufacturer who offers him the lowest wholesale price-the cartelist who is cheating. The presence of resale price maintenance will not make this type of cheating any easier to detect.

Furthermore, exclusive territories or other nonprice restrictions

1" 384 U.S. 127 (1966).

$2097 \mathrm{~S}$. Ct. at $2567-68$.

${ }^{21}$ Id. at $2558-59$ n. 18 . 
on dealer competition are also potential methods of shoring up a manufacturers' cartel. They prevent a cheater from arguing that any increase in his market share above the quota assigned him by the cartel was due not to his price cutting but to competition among his dealers. To be sure, nonprice restrictions would be effective in shoring up cartels only in exclusive dealing situations, but, as we saw, the effectiveness of resale price maintenance in shoring up cartels is similarly limited. In short, the possible role of restricted distribution in facilitating collusion at the manufacturer level does not distinguish price from nonprice restrictions. ${ }^{22}$

There is an even more fundamental objection to the Court's attempted distinction between resale price maintenance and nonprice restrictions on dealer competition. That resale price maintenance might sometimes be used to bolster a cartel at the manufacturer level cannot, under accepted legal standards, justify making the practice per se illegal. For example, under the test of Northern Pacific, which the Court in Sylvania quoted and endorsed, only arrangements which have a "pernicious effect on competition and lack . . . any redeeming virtue" 23 are per se unlawful. The fact that resale price maintenance might sometimes be used to bolster a cartel does not support the conclusion that it has a "pernicious effect on competition," which implies something more than a mere possibility of abuse. As for the second prong of the Northern Pacific test, the free-rider analysis, by which the Court found "redeeming virtue" in nonprice restrictions in distribution, applies equally to resale price maintenance. Telser originally developed the analysis to explain resale price maintenance.

The second basis for distinguishing between price and nonprice restrictions suggested by the Court in Sylvania was the recent repeal of the fair-trade exemption to the Sherman and Federal Trade Commission Acts. ${ }^{24}$ It is true that the legislative history reflects both a rejection of the justifications that have been offered for resale price maintenance and an awareness that the effect of repealing the exemption would be to throw it into the per se category. ${ }^{25}$ However, Congress's repeal of the fair trade exemption, even if motivated by

2 The approach to restricted distribution cases suggested below, see text and notes at notes 50-54 infra, is not designed to ascertain when restrictions on distributors are employed as an enforcement device by a manufacturers' cartel.

${ }^{23}$ Id. at 2558 (quoting White Motor Co. v. United States, 372 U.S. 253, 263 (1963) (quoting Northern Pac. R. Co. v. United States, 356 U.S. 1, 5 (1958))).

24 See Consumer Goods Pricing Act of 1975, Pub. L. No. 94-145, § 3 (1975), 89 Stat. 801 (amending 15 U.S.C. 45(a) (1970)).

${ }^{25}$ See H.R. REp. No. 94-341, 94th Cong., 1st Sess. (1975). 
dislike of resale price maintenance, was not a legislative decision to place the per se rule beyond the power of courts to reexamine. That issue was not put to Congress. Moreover, if the important thing is not what Congress did, but the antitrust view that led to this result, then since the policy considerations relative to resale price maintenance and nonprice restrictions are the same, the legislative history argues for preservation of the per se rule of Schwinn.

To appreciate the fragility of the distinction between price and nonprice restrictions in distribution, imagine that a few years from now a case involving a manufacturer accused of illegal per se resale price maintenance comes before the Supreme Court. This company is just like Sylvania-a small, faltering competitor whose market share rose after it adopted a restricted distribution system. The only difference is that because of the nature of this company's product (say, a pocket calculator) it is sold through numerous outlets located very close to each other. It would be utterly impracticable for this manufacturer to assign its dealers exclusive territories in order to stimulate the provision of presale services (display or local advertising or whatever): the territories would be only a few blocks in extent and policing adherence to territorial restrictions would therefore be impossible. Suppose the defendant proved that, because of these facts, it adopted resale price maintenance as the only feasible method of procuring dealer presale services that were both necessary and effective in enabling it to remain an effective competitor. How could the Supreme Court condemn this use of resale price maintenance consistently with the analytical foundations of the Sylvania opinion?

Dr. Miles is not the only precedent undermined by the freerider concept employed in Sylvania. In United States v. Sealy, Inc. ${ }^{26}$ decided the same day as Schwinn, the Supreme Court, in an opinion by Justice Fortas, held that an arrangement by which a group of small mattress manufacturers parcelled out exclusive territorial rights to sell under a common trademark was a per se illegal market division. The mattress manufacturers adopted this scheme not in order to charge a monopoly price for mattresses; the aggregate market share of the group, less than twenty percent, was too small to make this a plausible objective and in any event the members remained free to sell mattresses other than under the common trademark. Almost certainly they did it, rather, to overcome the

24388 U.S. 350 (1967). See also United States v. Topco Assocs., Inc., 405 U.S. 596 (1972). The Court in Sylvania distinguished Topco as involving a horizontal restraint. $97 \mathrm{~S}$. Ct. at $2562 \mathrm{nn} .27$-28. The significance of this distinction was not elaborated. Sealy was not cited. 
same kind of free-rider problem involved in restricted distribution cases. Without exclusive territories, one member of the group could take a free ride on the goodwill created by another member who promoted the Sealy name in his territory. The prospect of freeriding would reduce the incentive of each member to promote the Sealy name vigorously.

Another endangered precedent is Associated Press $v$. United States, ${ }^{27}$ in which the Court held that the Associated Press could not give its members veto power over the admission of new members. The Associated Press is a joint venture of newspapers. The newspapers belonging to it pool the news and information gathered by each member. In exchange for furnishing news to the pool, a member (before the Supreme Court's decision) obtained the exclusive right to distribute in its own market the news that other members furnished the pool. This system of exchange would be undermined if each member did not possess an exclusive right to AP news in its market-if, in other words, the association had to admit additional members in areas where it already had a member. The incentive to furnish the Associated Press with local news would be reduced if competitors who made any effort to gather news could receive as of right the news procured by industrious members.

B. More Endangered Precedents: Tie-in and Maximum-ResalePrice Cases

So far I have been discussing how the free-rider concept relied on in the Sylvania opinion may force a re-examination of precedents outside of the narrow area of nonprice restrictions on distribution. But the Court in Sylvania may have been making a broader point when it said:

Service and repair are vital for many products, such as automobiles and major household appliances. The availability and quality of such services affect a manufacturer's goodwill and the competitiveness of his product. Because of market imperfections such as the so-called "free rider" effect, these services might not be provided by retailers in a purely competitive situation, despite the fact that each retailer's benefit would be greater if all provided the services than if none did. ${ }^{28}$

This language, plus repeated intimations in the opinion that interbrand competition is more important than intrabrand competi-

\footnotetext{
${ }^{27} 326$ U.S. 1 (1945).

23 97 S. Ct. at 2561.
} 
tion, ${ }^{29}$ suggest a possible willingness to consider afresh the legality of restrictions on competition in the distribution process which do not prevent free-riding but which do enhance the manufacturer's competitiveness.

Perhaps the time has come to reconsider the per se tie-in rule as it has been applied to franchise distribution systems. As recently as the second Fortner decision ${ }^{30}$ the Court held that a seller who requires a buyer to take an unwanted second product as the condition of purchasing a product is guilty of an illegal per se tie-in, so long as the seller has at least some "economic power" over the desired product. The requirement of "economic power" is apparently satisfied by showing even a slight consumer preference for the tying product over competing goods. The lower federal courts have interpreted the tie-in rule as preventing franchisors from requiring their franchisees to buy products as a condition of retaining the franchise. For instance, Chicken Delight cannot require its franchisees to buy chickens from it; nor can Sinclair require its franchised gasoline dealers to buy tires, batteries, and other automobile accessories from it. ${ }^{31}$ Yet it is difficult to believe that Chicken Delight or Sinclair have more monopoly power than Schwinn or Sylvania. If the latter are allowed to prevent their dealers from selling outside assigned territories or to nonapproved outlets because they impose these restrictions only in order to enhance their own competitiveness, why should not Chicken Delight or Sinclair be permitted to restrict their dealers' purchasing freedom? These measures, too, enhance the franchisor's ability to compete and hence increase interbrand competition, which according to Sylvania is "the primary concern of antitrust law."32 A per se rule is no more appropriate for this situation than for the particular distribution restrictions imposed by Schwinn and Sylvania.

Some tie-ins are imposed by monopolists as a method of price discrimination, but tie-ins imposed by franchisors who are in competition with other sellers of the same product, just as Schwinn and Sylvania are in competition with other sellers of bicycles and television sets, are not of this kind. Franchise tie-ins are methods not of

2. See id. at 2559 n.19, 2560-61.

30 United States Steel Corp. v. Fortner Enterprises, Inc., 429 U.S. 610 (1977).

${ }^{31}$ See Siegel v. Chicken Delight, Inc., 448 F.2d 43 (9th Cir. 1971), cert. denied, 405 U.S. 955 (1972); Osborn v. Sinclair Refining Co., 286 F.2d 832 (4th Cir. 1960), cert. denied, 366 U.S. 963 (1961). Presumably, even under the most extreme view of the reach of the tie-in rule, Sinclair may "tie" its gasoline to its franchise-it cannot be required to allow dealers to sell some other gasoline company's gasoline under the Sinclair trademark.

$3297 \mathrm{~S}$. Ct. at 2559 n.19. 
discriminating or otherwise exploiting or extending monopoly power but of promoting interbrand competition by assuring quality control and product and service uniformity. This redeeming virtue should be enough under the principles of Sylvania to remove the franchise tie-in from the category of practices that are illegal per se.

It may be argued that the "goodwill defense" in tie-in law already protects the tie-in that promotes interbrand competition and therefore that Sylvania should have no impact on the law of tie-ins. However, the goodwill defense typically fails on the ground that the defendant could have protected his goodwill by other, less restrictive means, such as by promulgating and enforcing detailed product specifications. ${ }^{33}$ The basis of this approach-the notion that interbrand competition can be adequately protected by a per se rule subject to a defense judged under the least-restrictive-alternative standard-was, however, explicitly rejected by the Sylvania Court. It noted: "The location restriction used by Sylvania was neither the least nor the most restrictive provision that it could have used. But we agree with the implicit judgment in Schwinn that a per se rule based on the nature of the restriction is, in general, undesirable." 34

Still another precedent threatened by Sylvania is Albrecht $v$. Herald Co. ${ }^{35}$ The Court in Albrecht held that it was per se unlawful for a newspaper publisher to place a ceiling on the price at which its retail distributors could sell its newspaper to the consumer. Because the publisher had assigned the distributors exclusive territories, the most likely reason for the price ceiling was to prevent the distributor from using his distribution monopoly for his benefit rather than the publisher's. The logic of Sylvania is that restrictions imposed on dealers by manufacturers promote interbrand competition and are therefore not per se illegal, save perhaps if the manufacturer has a monopoly. That logic demolishes Albrecht.

\section{The New Importance of Economics}

Wholly apart from the Court's kind words for franchise restrictions and its adoption of the free-rider concept, certain language in the opinion concerning the use of economics to guide antitrust analysis can be expected to reverberate throughout the lower federal courts. The Court said that "competitive economies have social and

${ }^{33}$ See, e.g., International Business Mach. Corp. v. United States, 298 U.S. 131 (1936). Under the per se tie-in rule, the defendant bears the burden of proving that the tie-in was necessary to protect his goodwill. Id. at 138-39.

${ }^{34} 97$ S. Ct. at 2562 n.29.

3s 390 U.S. 145 (1968). 
political as well as economic advantages, but an antitrust policy divorced from market considerations would lack any objective benchmarks," 36 and that any "departure from the rule of reason standard must be based upon demonstrable economic effect." 37 One must not read a Supreme Court opinion like a bond indenture, but it does appear that the Court is implying that antitrust prohibitions must have an economic rationale and that the aesthetic delights of smallness and the yearning to resurrect a nation of sturdy Jeffersonian yeomen will not be permitted to decide antitrust cases. This impression is reinforced by the frequency of the Court's citations to the writings of members of the "Chicago School," like Bork and me, who argue that economic efficiency is the only goal of antitrust law..$^{38}$

Most of the antitrust rules limiting "vertical" restrictions (a restriction imposed up or down the chain of production and distribution, rather than between competitors) lack an economic basis, or, more precisely, have no stronger economic basis than Schwinn's per se prohibition of nonprice restrictions in distribution..$^{39}$ In fact, the Court in Sylvania intimated that all per se proscriptions of vertical restraints, mysteriously excepting the rule against resale price maintenance which it tepidly endorsed, are due for reexamination. The Court stated: "[W]e do not foreclose the possibility that particular applications of vertical restrictions might justify per se prohibition," 40 suggesting that it is prepared to reconsider all such prohibitions de novo, using the newly accepted economic approach." Tie-ins (not only in franchising), reciprocal buying, exclusive dealing, vertical mergers involving large market shares, boycotts-practices and transactions heretofore regarded as per se illegal or nearly so-may receive a more sympathetic judicial response in the wake of Sylvania.

\section{The Rule of Reason in Restricted Distribution Cases}

1. What Is the Rule of Reason? The Court in Sylvania did not hold that restrictions on competition at the distribution level are legal; it held only that such restrictions are to be tested under the Rule of Reason rather than automatically condemned. The Court

36 S. Ct. at $2559-60$ n.21.

I7 Id. at 2562.

3* See, e.g., id. at 2561.

39 See R. Posner, Antitrust Law: An Economic Perspective 171-211 (1976).

to $97 \mathrm{~S}$. Ct. at 2562.

"Read in context, "vertical restrictions" may refer only to nonprice restrictions in distribution. Or perhaps the Court was momentarily inattentive to the host of other vertical restrictions that the courts have held to be per se violations of the antitrust laws. 
did not, however, describe the Rule of Reason test. The opinion speaks as though the Rule of Reason were the normal standard for deciding antitrust cases and the per se concept the exception. The Court called the Rule of Reason the "prevailing standard of analysis" $\$ 2$ and implied that prior to Schwinn the standard was used many times in restricted distribution cases. Were this true, there would be no need to specify the meaning of the Rule of Reason as applied to restricted distribution. It is not true.

The Rule of Reason is rarely used to decide cases. Agreements among competitors are ordinarily condemned outright under the per se rule forbidding price fixing or its equivalents. Mergers are governed by reasonably specific rules evolved in decisions construing section 7 of the Clayton Act. Vertical restrictions other than mergers are governed by per se rules (for example, tie-ins), by rules developed in decisions interpreting section 3 of the Clayton Act (requirements contracts, for instance), or by rules developed in monopolization cases under section 2 of the Sherman Act. The reader is invited to compile a list of cases of which it may fairly be said that the Rule of Reason was the determinative legal standard. The list will be a short one.

The content of the Rule of Reason is largely unknown; in practice, it is little more than a euphemism for nonliability. Before Schwinn, restrictions on distribution were tested under the Rule of Reason, meaning: they were lawful. The Court in Sylvania may not have intended by its invocation of the Rule of Reason to bless all restrictions in distribution, but it was deceived if it thought it was subjecting those restrictions to scrutiny under a well-understood legal standard.

The Court's only effort to provide some content to the Rule of Reason was to quote from Justice Brandeis's opinion in Chicago Board of Trade:

The true test of legality is whether the restraint imposed is such as merely regulates arid perhaps thereby promotes competition or whether it is such as may suppress or even destroy competition. To determine that question the court must ordinarily consider the facts peculiar to the business to which the restraint is applied; its condition before and after the restraint was imposed; the nature of the restraint and its effect, actual or probable. The history of the restraint, the evil believed to exist, the reason for adopting the particular remedy, the purpose or end

$1297 \mathrm{~S} . \mathrm{Ct}$. at 2557. 
sought to be attained, are all relevant facts. This is not because a good intention will save an otherwise objectionable regulation or the reverse; but because knowledge of intent may help the court to interpret facts and to predict consequences. ${ }^{43}$

This is not a helpful formulation. To be told to look to the history, circumstances, purposes, and effects of a challenged restriction is not to be provided with usable criteria of illegality. If Justice Brandeis had said that the test was whether the restriction was on balance pro- or anti-competitive, this would at least have excluded criteria unrelated to competitiveness. Perhaps that is the meaning of the first sentence quoted above. Yet arguably competition should not be the exclusive determinant of an unreasonable restraint of trade. This formulation would prohibit those restraints that, while reducing competition, on balance increase efficiency. For example, it would bar a merger that gave the acquiring firm a monopoly but, in so doing, reduced the costs of serving the market to such an extent that the monopoly price after the merger was lower than the competitive market price had been before it.

Other formulations of the Rule of Reason are no more instructive. Illustrative is the formulation in Columbia Steel:

In determining what constitutes unreasonable restraint, we do not think the dollar volume is in itself of compelling significance; we look rather to the percentage of business controlled, the strength of the remaining competition, whether the action springs from business requirements or purpose to monopolize, the probable development of the industry, consumer demands, and other characteristics of the market. We do not undertake to prescribe any set of percentage figures. . . . The relative effect of percentage command of a market varies with the setting in which that factor is placed. ${ }^{44}$

Developed to guide the decision of merger cases, the Columbia Steel standard was quickly superseded in its original context by enactment of the Celler-Kefauver Antimerger Act in $1950 .{ }^{45}$ It was, however, later applied in the Times-Picayune case ${ }^{+6}$ to determine the reasonableness of a newspaper publisher's requirement that advertisers buy space in both the morning and evening editions. But

t3 Chicago Bd. of Trade v. United States, 246 U.S. 231, 238 (1918), quoted in 97 S. Ct. at 2557-58 n.15.

"United States v. Columbia Steel Co., 334 U.S. 495, 527-28 (1948).

t5 Act of Dec. 29, 1950, 64 Stat. 1125 (codified at 15 U.S.C. $\$ 18$ (1970)).

4 Times-Picayune Publishing Co. v. United States, 345 U.S. 594, 614-26 (1953). 
Times-Picayune is one of the very few Supreme Court cases in modern times in which the Rule of Reason was the rule of decision.

The Rule of Reason in its present state is a poor guide to the decision of restricted distribution cases. Its formlessness is clearly conveyed by the American Bar Association's recent monograph on restricted distribution. ${ }^{17}$ This sixteen-page discussion of how the Rule of Reason might be applied to restricted distribution cases invites the courts to consider whether the restraint is ancillary to a legitimate business purpose or anticompetitive in purpose; if the former, whether the restriction is reasonably necessary to accomplish the legitimate business purpose-and to this question " $[t]$ he degree of consumer acceptance of the product, the physical characteristics of the product and any unique marketing problems involved, the duration and scope of the intrabrand restraint, the strength of interbrand competition, and the acceptability of less restrictive alternatives might all be relevant"; 48 whether the defendant has market power, as determined by a study of market share, entry, and potential interbrand competition; the degree of product differentiation; a host of potentially exculpatory factors including the defendant's interests in maximizing market penetration, stimulating distributor service and other activity, and obtaining a market presence; and, finally, the effect of the challenged restriction on the survival of small business.

A start toward making the Rule of Reason more manageable is to adopt Professor Bork's position that the essential spirit of the Rule is to condemn only those practices that are, on balance, inefficient in the economic sense. ${ }^{49}$ This would exclude some of the factors listed in the standard formulation of the Rule of Reason. But without further particularization Bork's efficiency standard is insufficiently precise to guide the decision of restricted distribution cases.

2. Making the Rule of Reason Operational. There are at least two approaches to making the Rule of Reason a usable standard in cases involving restrictions on distribution. The first, loosely suggested by the Chicago Board of Trade formulation, is to require the trier of fact to balance the reduction in intrabrand competition against the increase in interbrand competition attributable to the restriction. To illustrate, the judge or jury would try to figure out how much money or welfare Sylvania's customers lost because its

17 See ABA Antitrust Section, supra note 10, at 55-71.

"Id. at 57.

"Bork, The Rule of Reason and the Per Se Concept: Price Fixing and Market Division, pt. 1), 74 YALE L.J. 775 (1965). 
dealers were not able to compete with each other and how much they gained because the location clause increased the presale services provided by the dealers. Besides requiring a trial of unmanageable complexity to quantify these impacts, this approach calls for an inquiry that is often unnecessary. Since Sylvania is not a monopolist, it would not knowingly impose a restriction on dealer competition that made the consumer of Sylvania products a net loser-that could only reduce Sylvania's sales and profits. Under this kind of balancing approach, the Rule of Reason would be used not only to prevent abuses of market power but to correct the mistakes of the powerless.

The second, and in my opinion vastly superior, approach is to focus on the single question whether the restriction is intended to cartelize distribution or, on the contrary, to promote the manufacturer's own interests. The goal is to isolate, and condemn, restrictions that are imposed nominally by the manufacturer but are in fact desired for monopolistic purposes by dealers using the manufacturer as their enforcement agent.

Under this test, many cases would be dismissed simply on a showing that the dealers' share of the relevant market was too small to give them the power to collude effectively. If American Motors has two percent of the U.S. automobile market and its dealers sell only American Motors cars, it is inconceivable that the purpose of giving American Motors dealers exclusive territories is to cartelize the distribution of automobiles. While it is true that, in principle, some (very few) consumers may so prefer American Motors to competing brands of automobiles that the dealers in those cars face as a group a downward-sloping demand curve, the slope is too close to being horizontal for courts to worry about dealer collusion..$^{50}$

The suggested approach would automatically preclude liability unless the manufacturer had a very large market share or unless all or most of the manufacturers in the market imposed uniform restrictions on their dealers so that (in either case) the dealers had a monopoly position in a genuine economic market. Where these conditions are satisfied, however, it may be quite difficult to determine whether the restriction is evidence of a dealers' cartel or of the manufacturer's wish to stimulate the provision of presale services. If no presale services (local advertising, display, and so forth) are

Io My suggested emphasis on market shares is consistent with the importance at tached to them in the early price-fixing cases, such as United States v. Addyston Pipe \& Steel Co., 85 F. 271 (6th Cir. 1898), aff'd as modified, 175 U.S. 211 (1899), before the per se rule against price fixing crystallized. 
in fact provided, this is strong evidence of cartelization. But even if extensive presale services are provided, that would not be conclusive evidence against cartelization; individual dealers might be stepping up service competition in order to capture as much of the profits generated by their cartel as possible. ${ }^{51}$

Where services are provided by dealers who dominate a relevant market, a possible way to distinguish a dealer cartel from a restriction that serves the manufacturer's interests is suggested by the fact that in the former situation limitations on dealer competition should reduce the output of the product in question while in the latter case output should increase. The object of the dealers' cartel is to raise the price of the good above its previous (competitive) level. If this goal is attained, the amount of the good demanded, and hence supplied, will fall (although sales may later rise as individual dealers add services in order to increase their sales at the higher price and in so doing shift their demand curve to the right). The manufacturer, in contrast, limits competition among his dealers in order to increase the value of and thus the demand for his product; and generally, although not invariably, a higher demand and hence a greater output will result from his effort. In Sylvania the defendant's market share increased after the imposition of the restriction (in Schwinn it fell), but it would take careful analysis, perhaps utilizing econometric methods, to determine whether the restriction was the cause of Sylvania's gain in sales or whether its sales would have increased even more without it. I would place on the government the burden of overcoming the inference created by Sylvania's sales gain that the location clause was in fact imposed for the manufacturer's benefit.

The Court in Sylvania considered Sylvania's increased sales revenues to be evidence that the challenged restriction was employed for Sylvania's benefit. ${ }^{52}$ The appropriate output measure, however, is physical quantity rather than revenue. Monopoly reduces physical output; sales revenues may or may not be greater (profits will of course be greater, at least in the short run). By

"11 The reader may wonder what difference it makes whether dealers engage in service competition because they are trying to maximize their share of a dealer cartel's profits or because the manufacturer restricts price competition; in either case the service competition and the resulting higher level of services provided consumers result from the elimination of price competition. The difference is that the manufacturer, acting voluntarily, will restrict dealer competition only to the extent necessary to evoke the optimal level of presale services. A dealer cartel might restrict dealer price competition much more, resulting in an excessive level of services and a net reduction in consumer welfare; or the dealer cartel might attempt to suppress service as well as price competition.

s2 97 S. Ct. at 2552. 
reducing demand for the product sold by the dealers, a dealer cartel will also reduce the dealers' demand from the manufacturer, causing his output to fall. Probably his revenues will also fall, because he does not benefit from the increase in the retail price brought about by the dealers' cartel. However, his revenues might rise were the dealers compensating him, in the form of a higher wholesale price, for acting as the cartel's policeman.

To summarize, I suggest a three-stage inquiry for determining the legality of restricted distribution, now that the inappropriate per se rule of illegality has been discarded (as should be clear, I would use this inquiry whether the restriction is price or nonprice in character):

1. Does the restriction embrace so large a fraction of the market as to make cartelization a plausible motivation for the restriction? If not, the restriction should be held lawful.

2. If the restriction does embrace a sufficiently large fraction of the market to make cartelization a possible motivation, do dealers in the product in question provide any presale services? If not, the restriction should be deemed unlawful. (An alternative would shift the burden of justification to the defendant at this point).

3 . If the answer to both of the previous questions is yes (large market share and presale services provided), did the manufacturer's output increase or decrease after imposing the restriction? If his output increased, the burden would shift to the government of showing that it increased for reasons unrelated to the restriction. If output fell after imposition of the restriction, the restriction would be deemed unlawful, unless perhaps the defendant could prove that he intended by adopting the restriction to increase his output.

The suggested guide may appear to overlook a much simpler method of determining the nature of the restriction, namely, by ascertaing whether it was imposed by the manufacturer or by the dealers. But this approach is unsound (and not really simple). Dealers as well as the manufacturer are hurt by free-riding; it is a detail whether the initiative in seeking to prevent free-riding was taken by the dealers or the manufacturer. This point was missed in Justice Fortas's opinion for the Court in the General Motors dealers case. ${ }^{53}$ The government briefed the case on the assumption that the main issue was the lawfulness of General Motors' location clause. The Court, demonstrating the same obsession with form at the expense of substance evinced in Schwinn and Sealy, ruled that because com-

33 United States v. General Motors Corp., 384 U.S. 127 (1966). 
peting dealers had collaborated to enlist General Motors' assistance in enforcing the location clause, the case involved an illegal per se horizontal conspiracy, regardless of the reasonableness of the clause. But if the clause was reasonable, the dealers should have been entitled to band together for the innocent purpose of persuading General Motors to carry out mutually beneficial contractual obligations.

Thus I disagree with Professor Bork's contention that detection of a dealer cartel is easy because of the large numbers of dealers who must join the cartel to make it effective. ${ }^{54}$ It may be easy to detect cooperative activity among the dealers but it is difficult to determine whether the purpose of the activity is to cartelize retail distribution or to overcome a genuine free-rider problem. The three-stage inquiry outlined above may be the simpler method of deciding this question after all.

\section{Conclusion}

The Supreme Court's Sylvania decision gives new prominence to the economic approach to antitrust law. Pursued to its logical conclusion, that approach requires the Court to reexamine a variety of other practices besides the nonprice distribution restrictions that were the subject of the opinion. But it must be admitted that economic science is more serviceable for deciding which practices should and which practices should not be classified as per se illegal restraints of trade than for guiding the trial of cases in which per se rules have been held inapplicable. Determining whether a challenged restriction on distribution is really a device for overcoming free-rider problems and hence increasing competition or whether it is a method of dealer cartelization is a formidable task. I have suggested a possible approach to this problem. Many hard questions remain unanswered, such as whether the three-stage approach should be used as the standard for adjudging criminal liability and, if not, how a criminal conspiracy among dealers to restrain trade could ever be proved, consistently with sound economic principles. It remains to be seen whether the law can develop rules for restricted distribution cases that will be at once effective and economically sound.

st Bork, Vertical Restraints: Schwinn Overruled, 1977 SuP. CT. REv. 171, 190-91. 